\title{
COVID-19 Outbreak Effects on Leadership, Job Satisfaction and Turnover Intention: A Mediating Model of Indonesian Banking Sector
}

\author{
Tedi Hidayat ${ }^{*}$, Rahmi Fahmy ${ }^{1}$, Dessy Kurnia Sari1 ${ }^{1}$ Fineke Mergeresa ${ }^{2}$, \& Yudi Fernando² \\ ${ }^{1}$ Faculty of Economics, Universitas Andalas, 25163 Padang, Indonesia \\ 2Faculty of Industrial Management, Universiti Malaysia Pahang, 26300 Pahang, Malaysia
}

ABSTRACT - This peper aims to determine and analyze the direct effect of transformational and transactional leadership on turnover intention, and indirect effect which is mediated by job satisfaction amid COVID 19 Pandemic at the banking sector. As many 153 permanent employees, including staff, supervisors, ass. manager, and division manager were participated. The results showed that transformational leadership has a positive but insignificant effect on turnover intention, while transactional leadership has a negative and significant affect turnover Intention. Furthermore, through mediating impact of job satisfaction, the effect of transformational leadership became negative and significant on turnover intention. Meanwhile, job satisfaction was significantly in line and strengthens the effect of transactional leadership on turnover intention at the banking sector amid COVID 19 Pandemic.

ARTICLE HISTORY

Received: 5-1-2021

Revised: $21-2-2021$

Accepted: 1-3-2021

\section{KEYWORDS}

Transformational Leadership;

Transactional Leadership;

Turnover Intention;

Job Satisfaction;

COVID-19;

Banking Sector

\section{Introduction}

The COVID-19 Pandemic continues to destructively impact countries throughout the world, and society feel stuck in a strange situation indeed. This situation triggered a worldwide crisis in the wake of the global pandemic, which has touched every angle of our lives, family, education, health, work, and even further, the relationship of leader and follower (Hinojosa et al., 2020). When people adapt to work on new realities, leaders in companies play a key role in framing the experiences of employees at the workplace during and post-pandemic (Ngoma et al., 2020). In most companies, the physical interaction between subordinates and leaders was disturbed by COVID-19 (Hinojosa et al., 2020). Leaders through their managerial level of communication still have a strong impact to follower performance, behavior, and emotional distress (Wu \& Parker, 2017). In the modern society, turnover intention has quickly become one of most important management issues, because it affects the integrity of company performance which induce the generally increasing trend of employee turnover worldwide (Sanjeev, 2017). For example, Park and Pierce (2020) argued that an average level of employee turnover in child welfare organizations varies from $20 \%$ to $57 \%$ a year, even $100 \%$ in several study (Fulcher \& Smith, 2010), and research recorded that as long as 2 years approximately $41 \%$ of employees were out of their jobs (Fallatah et al., 2017).

In the midst of COVID 19 pandemic, many companies reduce employee salary or even dismiss their employees to maintain stability and financial balance (Almeida \& Santos, 2020). Then, so many job vacancies were closed because many businesses went bankrupt (Han \& Goleman, Daniel; Boyatzis, Richard; Mckee, 2019). These things will impact the intentions of employee to resign from their current organization (Baum et al., 2020). People will keep having negative responses to survive in COVID 19 pandemic situations (ILO, 2020), the important things are how they and their family stay healthy, being not stress, and that their daily needs are met (ILO, 2020). This leadership style really helps to make the work environment optimal in articulating beauty of the vision, improving performance of employees and the organization as a whole (Yanney, 2014). Managers are advised to consistently improve effective communication and teamwork competency (Fernando \& Wulansari, 2021).

Furthermore, leaders must accomplish activities to increase employee's morale, and establish roles for groups or individuals in achieving goals (Awan \& Mahmood, 2010), and style is one of the ways a leader characterized to handle organizational matters. Various styles can be applied in leadership, and each style has a series of advantages and disadvantages, and each are different from each other (Randeree \& Chaudhry, 2012), difference in work set will direct leader to implement different style (Tajaddini \& Mujtaba, 2011), and different places will also need different style in implementations. In this study, we have identified several problem including religious issue, lack of career advancement, employee job satisfaction, and leadership implementation.

In case of the company, it is very important to reflect what the company has done to meet the needs of employees to retain effort, to measure their service, the company also need to consider employee satisfaction on the job. In research by (Ramalho Luz et al., 2018), most important factors which affected turnover intention are job satisfaction, and leadership style (Westover, 2014; Xie et al., 2018), a high quality and strong relationship between employee and leader will be created when employees are satisfied with their leader and vice versa. In the same way, Hassan and Jagirani (2019) which is conducted a study in the banking sector in Pakistan, 200 samples were chosen and found that job satisfaction has a negative and significant effect on employee turnover intention. It means that if employees feel very satisfied, they tend 
to be loyal to the organization while unsatisfied employees have a tendency to switch to another organization. It is critical to examine job satisfaction, leadership role and turnover in the banking industry during a COVID-19 pandemic. There is not much empirical data in the literature about how work satisfaction and employee behavioural intentions change before and during the COVID-19 pandemic. Committed employees can help the company gain competitive advantages from the competitor (Mohter \& Fernando, 2020). This paper aims to determine and analyze the direct effect of transformational and transactional leadership on turnover intention, and the indirect effect which is mediated by job satisfaction amid COVID 19 pandemic in Indonesian banking industry.

\section{Literature Review}

Turnover Intention

According to Takase (2010), turnover intention is a process which came from a negative psychological response to organizations conditions and specific job conditions which makes employees resign from an organization. Clasical literature such as Dalton and Todor (1979), highlighted there are some negative and positive impact for the organization such as financial cost, lack of productivity, reduced work effectiveness, impact in social networks and communication, loss of expertise/ know-how; and reduced morality (Ramalho Luz et al., 2018). In the individual level, reasons such as the desire dedicate more time for family business, moving due to spouse job, and to enjoy in another activity are common. The people who remain in the organization are also affected when they start to ask about their careers and feel the absence of their job colleagues (Stamolampros et al., 2019). Moreover, employees can be overworked by being given activities of the employees who leave the organization (Ramalho Luz et al., 2018). The excessive turnover also may increase costs of production and result in a deficient productive capacity, due to lack of trained people, the absence of qualified professionals in a determined region may result in an Non-viable determined operation, thus affecting the region socioeconomically (Silva, 2013). Among the positive impact of turnover, there is oxygenation for an organization, bringing other persons with expertise, ideas, new knowledge, and professional experiences. Following the same rationale, (Dalton \& Todor, 1979; Nolan-Arañez \& Ludvik, 2018) provided several ways in which turnover may increase organizational effectiveness such as through reduction of conflicts in extreme cases, increase of internal mobility due to new opportunities coming in, stimulus to innovation and flexibility, increase in employees' moral when an undesired superior or colleague leaves the organization (Ramalho Luz et al., 2018).

\section{Transformational Leadership}

In the past, Bass and Avolio (1993) and Northouse (2001) argued that transformational leadership is a leadership behavior which affect followers to go beyond their individual interests for collective goals of the organization, they help followers reach their full potential by paying attention to individual needs related with motivation and morality of followers (Park \& Pierce, 2020). Burns (2005), Reid and Dold (2018) argued that transformational leadership style also encourages employees to achieve a higher stage of demand and build a habit of trust between leaders and group members. So that, group members be aware of how important their tasks are (Xie et al., 2018). Leaders raise awareness of members to observe future goals and mission of group by expanding and enhancing interest of their employees, encourage their employees to go beyond their self-interests for common goals (Amankwaa \& Anku-Tsede, 2015). They are more focused on developing morality, skills, employee's overall value, and employee motivation, and its looks like a solid foundation in building relationships by providing a clear understanding value of a relationship and shared interests (Khajeh, 2018).

\section{Transactional Leadership}

According to Bass and Avolio (2004), transactional leadership uses corrective and constructive transactions to make sure followers do their expected tasks, and leaders really want to exchange anything with work (Bright, 2018). They are reward-punishment based leadership, and have work standards that strictly adhere to standard operational procedures (SOP), so that makes their leadership style less flexible. When the organization is in a stable condition, the transactional leadership style is often used and very useful for the organization to cover balancing organization performance and hold it (Sithole \& Sudha, 2014). Chen and Shi (2007) highlighted that leaders that use transactional leadership style support group members in completing their jobs, and attaining self-fulfillment. It aims to make leaders and group members to benefit from each other (Xie et al., 2018).

\section{Job Satisfaction}

Castle et al. (2007) defined job satisfaction as the belief in the amount of pay that employees must get for the differences in rewards received, and becomes a general attitude towards their assessment of work. Besides, job satisfaction is related to what they really get and what they expect from it (Dartey-Baah \& Ampofo, 2016). Then, it will be represented by positive or negative behavior that employee showed in workplace (Adiguzel et al., 2020; Spector, 1997). There are several factors that have been found in banking sectors that influence job satisfaction, including working hours, working conditions, payment, work design, promotions, demographic features, human resource development, leadership style, and level of stress (Bhardwaj et al., 2020).

\section{Hypothesis development}

Leaders who use transformational style of leadership encourage subordinates to observe an environment that raises doubts, then ask subordinates to propose effective and unique solutions to the leader, and leaders also encourage their 
subordinates to challenge themselves and continue to innovate through motivation, future inspiration, intellectual stimulation, care and concern (Xie et al., 2018). Indirectly, this will strengthen employee engagement, change their mindset, and their beliefs to be loyal for organization, and as result, turnover intention will be decreased (Gul et al., 2012). Several studies provide evidence for this (Amankwaa \& Anku-Tsede, 2015; Maaitah, 2018; Park \& Pierce, 2020; Sahu et al., 2018). We also argue that maximizing the role of transformational leadership can help organization to mitigate turnover intention.

On the other hand, transactional leaders are beneficial to small organizations as they are simple and low cost, clear and easy to follow, and it would help to produce results quickly (Sithole \& Sudha, 2014). Yanney (2014) argued that transactional leadership style was found to be supportive in maintaining and creating a context in which human and organizational capabilities are maximized, because employees can often achieve both visible and invisible rewards. They really help to make work environment to be optimal in articulating beauty of vision, improving employee performance, and organization as a whole (Yanney, 2014), and also very effective in finishing specific task by concentrating on individual portions (Sithole \& Sudha, 2014). Deraman et al. (2018) found that the active management by exception and contingent reward leadership has a strong and negative effect in mitigating turnover intention in manufacturing industry Peninsular, Malaysia.

The influence of transformational leadership styles on overall job satisfaction was evidenced by Alonderiene \& Majauskaite, 2016; Ho et al., 2016; Mickson \& Anlesinya, 2019; Dartey-Baah \& Ampofo, 2016; Hassi, 2019), In which due to the close relationship between employee and employer, leaders will have a better ability to know the employees' needs and wants.Then, reward based leadership also was beneficial in fulfilling employee expectations, Because rewards are given in proportion to how much the leader thinks the employee has performed and produced good quality work (Dartey-Baah \& Ampofo, 2016). There are several study that became evidence in positive and significant relationship between transactional leadership and job satisfaction (Alonderiene \& Majauskaite, 2016; Dartey-Baah \& Ampofo, 2016; Hassi, 2019; Ho et al., 2016). By understanding members needs fully, and defining leader roles in retaining effort. Then proposed hypothesis is:

\section{H1: Transformational Leadership has a negative and significant effect on turnover intention \\ H2: Transactional Leadership has a negative and significant effect on turnover intention \\ H3: Transformational Leadership has a positive and significant effect on job satisfaction \\ H4: Transactional Leadership has a positive and significant effect on job satisfaction}

The tendency of employees to be loyal to the organization becomes high if they are satisfied with their work, and vice versa (Hurt et al., 2017). In addition, job search activities will increase when employees feel dissatisfied, and they will stay for a longer time when satisfied (Hurt et al., 2017). Furthermore, it will be increasing turnover intentions rate (Ramalho Luz et al., 2018). Many studies have found that job satisfaction is associated with increased production, organizational performance, and loyalty to banks (Bhardwaj et al., 2020), so that the higher level of employee satisfaction will make level of turnover intention lower (Herschell et al., 2020; Wang et al., 2020; Wells \& Peachey, 2011). These results are then reflected by negative behavior and the presence of anxiety, such as successive absences and lack of control in job presentation (Bhardwaj et al., 2020). Several studies have shown that a high level of job satisfaction can reduce turnover intention (Carlson et al., 2017; Hassan \& Jagirani, 2019; Koesmono, 2017; Sanjeev, 2017; Zhang et al., 2019). Then, we propose:

\section{H5: Job satisfaction has a negative and significant effect on turnover intention}

Transformational leadership is one of the key factors affecting employee job satisfaction, when an employee feels very satisfied with leader role and quality, thus turnover intentions will decrease (Grau \& Heuschmann, 2020). In a study by (Wang et al., 2020), job satisfaction succeed as mediator to turnover intention, the impact of job satisfaction make employee feel engaged and loyal to organization. While transactional leadership focuses on rewards between follower and leader, and task-related exchange of actions, they will appreciate when employee's work matches their expectations (Anis Amirah Muhd Suberi, 2013), leaders exhibit leadership behaviors and having tendency to set goals for their employees and rewards which can be obtained for their achievements, for these context leaders actively monitor organization goals to achieve good result, and to guarantee employees satisfactions they really care and know much about employees needs and wants (Mickson \& Anlesinya, 2019). In (Scanlan \& Hazelton, 2019), job satisfaction also succeed as a mediator in their study which was conducted in Australia. High level employee job satisfaction will create a healthy relationship between leaders and follower (Moon \& Park, 2019), and through maximizing overall job satisfaction can be enhancing leadership role in mitigate turnover intention. Then the following hypothesis were proposed:

\section{H6: Job Satisfaction mediates the effect of transformational leadership on turnover intention H7: Job Satisfaction mediates the effect of transactional leadership on turnover intention}

\section{MethodS}

Type of sampling design in this study is probability sampling and in the process of selecting samples, this paper uses stratified proportionate random sampling as a technique. This means that we subdivide the employees into those homogeneous groups or stratify the employee population by the division in which they are specializing (Dunn et al., 2003; Sekaran \& Bougie, 2011). To calculate, we refer to a formula by Dunn et al. (2003). Then, size of sample required refers 
to (Krejcie \& Morgan, 1970) which simplified the decision of size by providing a table to ensure proper decision model, and in this study $n=256$, so that according to those table we establish to take $n=153$, because our sample size in between 250- 260. The population consisted of bank employees within the West Sumatera branch area. Then, sample will be chosen by using lottery method in accordance with portions from each division (Sekaran \& Bougie, 2011), and our participant focused onto permanent employees.

Table 1: Respondent Profile

\begin{tabular}{|c|c|c|c|}
\hline Participants Profile & $\%$ & Participants Profile & $\%$ \\
\hline Male & $60,78 \%$ & $<1$ year & $5,88 \%$ \\
\hline Female & $39,22 \%$ & $1-5$ year & $23,53 \%$ \\
\hline$<20$ year & $2,61 \%$ & 6- 10 year & $26,15 \%$ \\
\hline 21- 30 year & $21,57 \%$ & $>10$ year & $44,44 \%$ \\
\hline 31- 40 year & $43,79 \%$ & Islam & $100 \%$ \\
\hline$>40$ year & $32,03 \%$ & Others & $0 \%$ \\
\hline Married & $84,31 \%$ & Division Manager & $3,92 \%$ \\
\hline Single & $13,73 \%$ & Ass. Manager & $9,81 \%$ \\
\hline Widow & $0,65 \%$ & Supervisor & $12,42 \%$ \\
\hline Widower & $1,31 \%$ & Staff & $73,85 \%$ \\
\hline < IDR 3 million & $8,50 \%$ & Sharia Bank & $62,09 \%$ \\
\hline IDR 4- 6 million & $17,00 \%$ & Conventional Bank & $37,91 \%$ \\
\hline IDR 6- 8 million & $37,25 \%$ & Suitable & $94,78 \%$ \\
\hline > IDR 8 million & $37,25 \%$ & Not Suitable & $5,22 \%$ \\
\hline SHS/ VHS & $0,65 \%$ & Ever & $43,48 \%$ \\
\hline Diploma III & $13,08 \%$ & Never & $37,56 \%$ \\
\hline Bachelor Degree & $75,16 \%$ & On Process & $18,96 \%$ \\
\hline Master Degree & $11,11 \%$ & & \\
\hline Doctoral & $0 \%$ & & \\
\hline Work Style Amid COVID 19 / June 2020 & & Work Preferences Post COVID 19 & \\
\hline Full WFH & $9,80 \%$ & Full WFH & $2,61 \%$ \\
\hline Mix WFH and WFO & $0 \%$ & Mix WFH and WFO & $19,60 \%$ \\
\hline Full WFO & $90,20 \%$ & Full WFO & $77,79 \%$ \\
\hline
\end{tabular}

With regards to data collections, we used primary and secondary data, including interviews to obtain preliminary data regarding the phenomenon, and questionnaires by using paper questionnaires instead of online. In term of distributing procedure, the numbers established in calculation of stratified proportionate random sampling on each divisions followed (Sekaran \& Bougie, 2011), and 14 divisions are included. As much as 170 questionnaires were distributed and 158 were completed. Then, 153 were chosen as complete questionnairess to be analyzed. The questionnaires used had two sections. First section contains participants profile, and second section contains measurement scale of four variables by using 1 to 5 likert scales. After questionnaires were return, the data were analyzed by using technique of Structural Equation Model (SEM) with assisting of Smart PLS 3 software (Hair et al., 2014).

\section{Finding and discussion \\ Participants Profile}

Participants profile seen in (Table 1) above, a majority of participants in this research is male $(60,78 \%)$ and female $(39,22 \%)$, with $2,61 \%$ ages < 20 years, $21,57 \%$ ranges 21 to 30 years, $43,79 \%$ in ranges 31 to 40 years, and $32,03 \%>$ 40 years, $84 \%$ were married, $13,73 \%$ single, $0,65 \%$ widow, and 1,31\% widower. In terms of income, our research participants as many as $8,50 \%$ has received < IDR 3 millions, $17 \%$ in ranges of IDR 4 to 6 millions, 37,25\% in ranges of IDR 6 to 8 millions, and 37,25\% more has received > IDR 8 millions monthly. A majority of participants have a bachelors degree with $75,16 \%$, master degree $11,11 \%$, diploma III 13,08\%, SHS/VHS 0,65\%, and no doctoral degree participated in this study. All of them are Muslim, with length of work 5,88\% < 1 year, 23,53\% in ranges 1 to 5 years, 26,15\% in ranges 6 to 10 years, and 44,44\% > 10 years. As many as 3,92\% grade divisions manager, 9,81\% as assistant manager, $12,42 \%$ supervisor, and 73,85\% staff were participated. Most of them prefer Bank Nagari shift to sharia bank (62,09\%) than conventional bank $(37,91 \%)$. In work placement, $94 \%$ participants said suitable, only 5,22\% not suitable, as many $43,48 \%$ had been promoted, $37,56 \%$ never, and $18,96 \%$ on process. When we ask their working style amid COVID 19 since June 2020, 9,80\% experienced full WFH, 90,20\% full WFO, and no employee experienced both of it. Furthermore, in post-COVID 19 our participants prefer to WFO (77,79\%) than WFH $(2,61 \%)$, and 19,60\% participant prefer a combination.

\section{Descriptive Analysis}

By describing the data that has been collected properly without any intention to making generalizations results, the writers conduct a descriptive analysis to assess and see participants' responses to indicators proposed (Hair et al., 2010; O'Fallon et al., 1973). In turnover intention indicate statement "I almost always think about quitting my current job" has 
highest mean value of 2,62 with total responses $52 \%$ of all instruments used, it is induced by expectations regarding their position, careers development and advancement, or benefits that might be more in line with their expectations, and also maybe this is due to thoughts about fear of looking for a new job due to the impact of the COVID 19 pandemic. While in the statement "I will leave the organization as quick as I can" has lowest mean value of 2,35 and $47 \%$ total responses, it might be due to unclear situation amid COVID 19 pandemic, the situations change employees mindset to be scared of leaving their comfort zone. They tend to be patient with negative things which may their feel in workplace, because of their choices are limited during pandemic.

\begin{tabular}{|c|c|c|c|c|c|}
\hline & Indicators & Score & Mean & TPR & Category \\
\hline \multicolumn{6}{|c|}{ Turnover Intention (Y) } \\
\hline Highest & I almost always think about quitting my current job & 401 & 2,62 & $52 \%$ & Sufficient \\
\hline Lowest & I will leave the organization as quick as I can & 359 & 2,35 & $47 \%$ & Low \\
\hline \multicolumn{6}{|c|}{ Transformational Leadership (X1) } \\
\hline Highest & Emphasizes the collective mission & 616 & 4,03 & $81 \%$ & High \\
\hline Lowest & Goes beyond self-interest & 435 & 2,84 & $57 \%$ & Sufficient \\
\hline \multicolumn{6}{|c|}{ Transactional Leadership (X2) } \\
\hline Highest & Rewards your achievement & 555 & 3,63 & $73 \%$ & High \\
\hline Lowest & Delay responding & 350 & 2,29 & $46 \%$ & Low \\
\hline \multicolumn{6}{|c|}{ Job Satisfaction (M) } \\
\hline Highest & Satisfied with work placement & 604 & 3,95 & $79 \%$ & High \\
\hline \multirow[t]{2}{*}{ Lowest } & Satisfied with career advancement & 528 & 3,45 & $69 \%$ & High \\
\hline & $\begin{aligned} * \text { Note: } & n=153 \text { Participants } \\
& T I=3 \text { indicators } ; T F L=20 \text { Indicators } \\
& T S L=16 \text { Indicators } ; J S=18 \text { Indicators }\end{aligned}$ & & & & \\
\hline
\end{tabular}

In transformational leadership, "emphasizes the collective mission" have highest mean value as many as 4.03 and $81 \%$ total responses. This means that, in general, participants in the study admit their leaders prioritize common goals in work or office assignments, leaders prioritize teamwork than work that they might be able to complete on their own. ” Goes beyond self-interest" had lowest mean value of 2.84 and $57 \%$ total responses, meaning that the leader in the banking sector when under certain conditions more often prioritizes personal interests than common interests, this can also be interpreted as meaning that if leaders are faced with choices, then they will prefer their own interests than common interests, and this may be repeatedly seen by staff or the majority of participants in this study. Even authors assume leaders also will not sacrifice their personal interests which might be beneficial for themselves than the sake of common interests. This reason is logically acceptable, because in the midst of the difficult situation of the COVID 19 pandemic era, a person has a tendency to focus on their own needs (ILO, 2020). In transactional leadership, 16 indicators were used to measure this variable (Avolio et al., 1999). The highest mean value is "rewards your achievement", with a mean value of 3.63 and $73 \%$ total responses, it indicates that almost every employee achievement has been rewarded by bank companies through their leaders, and its also will clearly make employees more excited because their achievements will not be in vain. In other words, almost every leader's expectations are met in a work context so that they will be rewarded for it. the lowest mean value stated "delay responding" which is 2.29 mean value with $46 \%$ total responses. It has proven that the leaders at the banking sector almost never delayed their response, and that the leaders are very responsible for their functions and roles.

In term of job satisfaction, 18 indicators were used (Lee \& Way, 2010; Ramalho Luz et al., 2018), in which when adopted both sources of indicators then modified by the writers, its aim was to make it match with current situations and the problems identified at banking sector. The highest mean value is 3,95 with 79\% total responses, stated that employees feel "satisfied with work placement", it's proven that majority of our participants felt that they were placed in an expected location in which has good quality work environment, good work facility, secure, easy access and make them feel comfortable when they do their work, it is also because they placed in the centre office. The lowest mean value is 3,45 with $69 \%$ total responses, in which there was a lack for "satisfied with career advancement". It is indicated that our participants were not fully satisfied with their career prospect, the writers assume that still there are unequal or unfair actions for job promotions. A clear timeline is very important for employees at banking sector, because when employees know in what years they will get promotion, then they will be more motivated to complete job task on time, they will prepare them self if the promotion forced or take place in another location. In case of our study, we identified that several employees resigned from banking sector due to sudden transfer process without mature considerations or unfair sudden job rotations and also several of employee feel isolated in career advancement and development. If the promotions are not clear, either related with times, suitable department or location, thus it will make promotion and career advancement become a scary instead of a happy situation. 


\section{Validity and Reliability}

Average Variance Extracted (AVE) value is another measure of convergent validity. The AVE value describes the variety of manifest variables or amount of variance that a latent construct can have. Therefore, the greater variance or variety of manifest variables that can be contained by latent constructs, the greater the manifest variable representation of the latent constructs (Fornell \& Larcker 1981), they recommended AVE for a criterion to assessing convergent validity which has a minimum value of 0.5 , and it indicates a good measure of convergent validity. The 3 showed AVE score after several invalid indicators in outer loading were deleted, all variables have values of more than 0,5 and declared valid. The detailed information about values on each variable, including transformational Leadership has 0,541 , transactional leadership has 0,589 , job satisfaction has 0,546 , and turnover intention has 0,917 AVE value.

Table 3: Validity and Reliability

\begin{tabular}{lccc}
\hline & AVE & Cronbach's Alpha & Composite Reliability \\
\hline Job Satisfaction & 0,546 & 0,951 & 0,956 \\
Transactional Leadership & 0,589 & 0,819 & 0,875 \\
Transformational Leadership & 0,541 & 0,950 & 0,955 \\
Turnover Intention & 0,917 & 0,954 & 0,971 \\
\hline
\end{tabular}

The reliability of a measure is established through testing for both stability and consistency (Sekaran \& Bougie, 2011; Fernando et al., 2021). The most frequent measurement used for internal consistency refers to scores of cronbach alpha and composite reliability, it aims to find out the extent to which the measurement tool has consistent accuracy, the construct is declared reliable if the composite reliability and cronbach alpha scores $>0.7$, There are several classifications in reliability score, includes $>0,7$ acceptable, $>0,8$ good, and $>0,9$ classified has excellent reliability (Heale \& Twycross, 2015; Hair et al., 2010; Sekaran \& Bougie, 2011). The result of a reliability test seen in (Table 3) above, in which each variable has cronbach alpha and composite reliability scores $>0.7$ which is a predetermined prerequisite to be declared acceptable, and scores on each variable even exceeded 0.8 and even 0.9 , then it can be said that the tested variables have good reliability. Furthermore, there is another way to assessing validity of each indicator used, it is by conducting discriminant validity (Ab Hamid et al., 2017; Henseler et al., 2014; Hair et al., 2010; Wahyuni-TD et al., 2021). Discriminant validity is comparing the square root of average variance extracted (AVE) value of each construct with the correlation between other constructs in the model, if the square root of average variance extracted (AVE) construct is greater than its correlation with all other constructs it is said to have good discriminant validity (Henseler et al., 2014).

Table 4: Discriminant Validity

\begin{tabular}{lcccc}
\hline & JS & TSL & TFL & TI \\
\hline Job Satisfaction (JS) & 0.739 & & & \\
Transactional Leadership (TSL) & 0.635 & 0.767 & & \\
Transformational Leadership (TFL) & 0.650 & 0.697 & 0.736 & 0.957 \\
Turnover Intention (TI) & 0.497 & 0.487 & 0.386 & \\
\hline
\end{tabular}

Analyzing the relationship of latent variables, in general, the accepted prerequisite is assessing discriminant validity in which the Fornell- Larcker criterion is the approach that is most often used for variant-based structural equation modeling in evaluating research models (Claes Fornell \& David F. Larcker, 1981; Henseler et al., 2014). Discriminant validity seen in (Table 4), appears that intended construction has a higher value than other constructs, and the value for each construction exceeds 0.7 then it can be declared to have a good discriminant validity and Fornell- Larcker Criterion passed.

\section{Hypothesis Result}

This study determined the hypothesis by using boostrap analysis in PLS-SEM to observe inferences on data set. There are seven proposed hypothesis: five relates to direct effect and two for indirect effect. The hypothesis can be declared supported if t-statistic > 1,96 t-table, and vice versa (Sekaran \& Bougie, 2011). Then, for relationship effect can be seen in the original sample value or coefficient value which indicates negative or positive relationship, and for significance level P values should less equal than $5 \%$ (Hair et al., 2014). Table 5 and Figure 1 shows the results of hypothesis testing. 
Table 5: Results of hypothesis testing

\begin{tabular}{llccccc}
\hline Hypothesis & Path & Std. Beta & SE & T-value & P-values & Remarks \\
\hline$H 1$ & TFL -> TI & 0,040 & 0,101 & 0,400 & 0,345 & NS \\
$H 2$ & TSL -> TI & $-0,307$ & 0,118 & 2,597 & 0,005 & Supported \\
$H 3$ & TFL -> JS & 0,402 & 0,093 & 4,307 & 0,000 & Supported \\
$H 4$ & TSL -> JS & 0,355 & 0,090 & 3,964 & 0,000 & Supported \\
$H 5$ & JS -> TI & $-0,328$ & 0,129 & 2,536 & 0,006 & Supported \\
$H 6$ & TFL -> JS -> TI & $-0,132$ & 0,053 & 2,485 & 0,007 & Supported \\
$H 7$ & TSL -> JS -> TI & $-0,117$ & 0,053 & 2,217 & 0,014 & Supported \\
\hline
\end{tabular}

Note: NS $=$ Not Supported

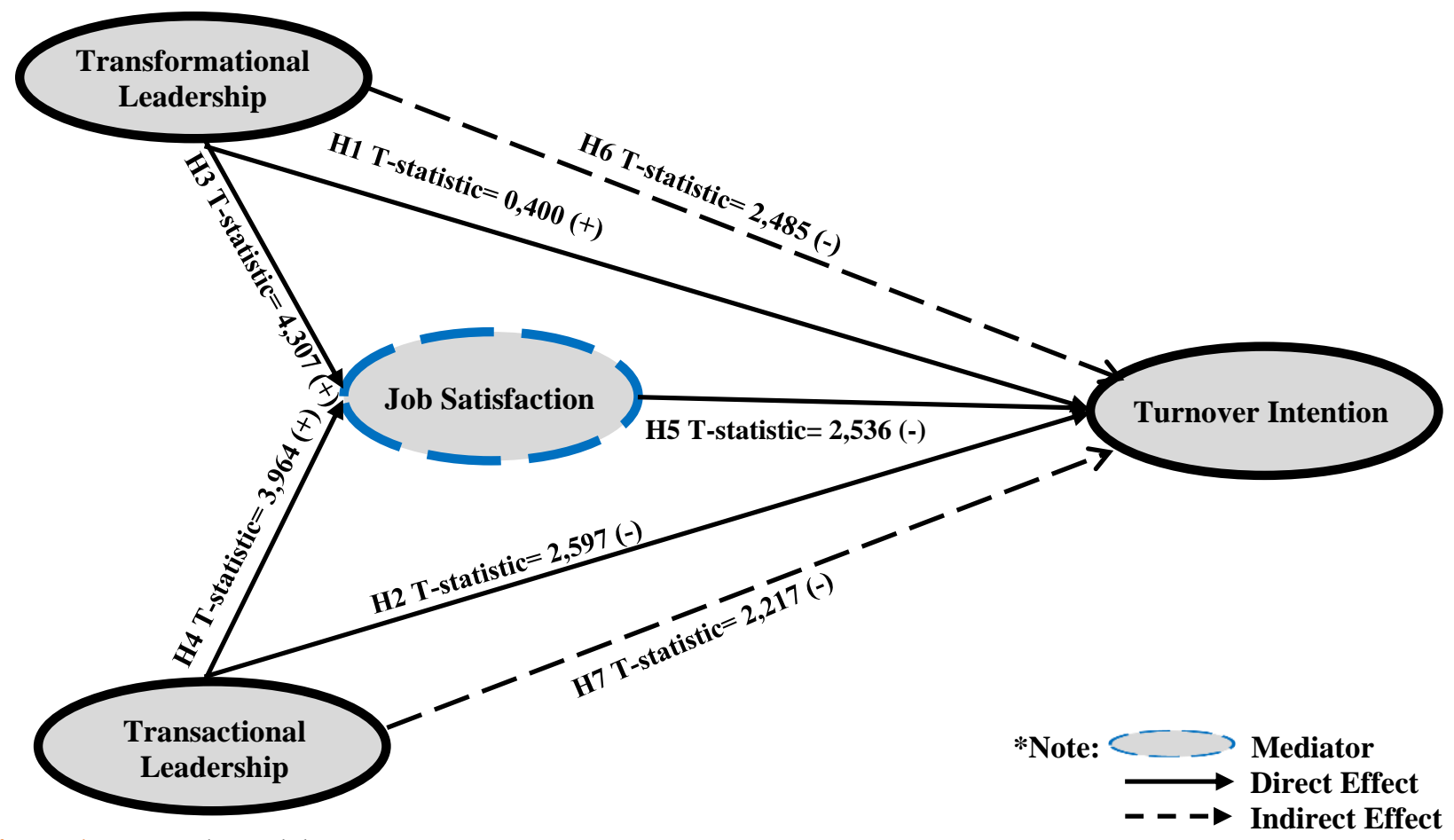

Figure 1: Research Model

We found that transformational leadership has a positive but insignificant effect on turnover intention, in which has a tstatistic $0,400<1,96$ with $\mathrm{P}$ value $>0,05$ is 0,345 , and original sample indicates positive relationship. It can be said that $H 1$ was not supported, and for justifications will be detailed in the discussion section. Then, transactional leadership has negative and significant effect on turnover intention, in which has t- statistic 2.597>1,96 with $\mathrm{P}$ value 0,005 and original sample indicated negative relationship. It can be said $H 2$ was supported. Meanwhile, both transformational and transactional leadership has positive and significant effect on job satisfaction, in which transformational has a t- statistic 4,307 > 1,96 t-table with $\mathrm{P}$ value 0,000 and original sample indicated positive relationship, while transactional leadership has t- statistic 3,964 > 1,96 t-table with $\mathrm{P}$ value 0,000 and original sample indicate positive relationship, $H 3$ and $H 4$ can be declared supported. In the relationship between job satisfaction and turnover intention, job satisfaction has positive and significant effect on turnover intention, in which has t-statistic 2,356>1,96 with $\mathrm{P}$ value $0,006<0,05$, and original sample indicated a negative relationship, meaning that $H 5$ also supported. For indirect effect, job satisfaction successfully and significantly mediates the relationship between transformational leadership and turnover intention with $\mathrm{t}$-statistic value is $2.485>1.96 \mathrm{t}$-table, and $\mathrm{P}$ - value $0,007<0,05 \mathrm{P}$-value required, in which original sample indicates negative relationship to turnover intention. Meanwhile, the mediating impact of job satisfaction in relationships between transactional leadership and turnover, also succeed and significantly impacted, in which it has a t-statistic 2,217 >1,96 ttable, $\mathrm{P}$-value $0,014<0,05 \mathrm{P}$-value required, and the relationship is also negative to turnover intention. Thus it can be declared $H 6$ and $H 7$ were supported.

\section{Discussions}

Transformational Leadership On Turnover Intention

The results found that transformational leadership has a positive but insignificant effect on turnover intention at Indonesian banking sector. When leaders emphasize collective missions, that the behavior should be supported by leaders which also tend to behave goes beyond their self-interest. But, our descriptive result found the leaders lack to go beyond 
his self-interests, with lowest mean value of all indicators. Meaning that, the leader in the banking sector when under certain conditions more often prioritizes personal interests than common interests, it also can be interpreted as meaning that if leaders are faced with choices, then they will prefer to meet their own interests than common interests, and this may be repeatedly seen by staff or the majority of participants in this study. This reason is logically acceptable, because in the midst of the difficult situation of the COVID 19 pandemic era, a person has tendency to behave in a more individualistic manner (ILO, 2020).

This study argue that inconsistency creates employee distrust, resulting in a loss of motivational power from leaders to inspiring followers. Another reason was, an average employee have an age of over 30 years with work experience more than 6 years, and education that is almost evenly distributed in undergraduate level. These things have an impact for loss of functions of the leader's visual motivation towards employees. Besides that, along with the COVID 19 pandemic, almost everyone thinks about themselves, security, and needs, and that includes the leader himself, and they are less focused on the quality of work (Aguinis et al., 2020). Regarding voluntary turnover, when an employee intends to leave the organization, they will go through a cognitive process of thinking about quit, planning to leave, and having a desire to leave current job (Gemeda \& Lee 2020). It is clearly closeness related to employee behavior in COVID 19 crisis pandemic (Baum et al., 2020). Transformational leadership dimension in the COVID 19 pandemic era has even led to the intention of employees to leave their current jobs if leaders were not consistent. Referring to the results of this study, we did not find supporting literacy with same result. However, in an abnormal situation, it is very natural if it happens, because the behavior of employees tends to be individualistic (Hamid, Mahmud, Wahab, Sazali Abdul, Hosna, 2020).

On the other hand, the role conflict between taking care of school children and feeling very busy with multiple functions, make employees ignore motivations given causes by lack of trust, in which 90 percent of participants are married. In term of employees who work in banking sector, customer service, or any position, the direct communications will be severely hampered by COVID-19 (Wang et al., 2020), and when communication was forced, especially in terms of motivation, inspiration, it will have the opposite effect to turnover intention. Logically, it will make distrust and turn the relationship between leaders and followers less harmonious when unsuitable words and actions were shown. Trust is defined as an expectation or belief that one can depend on another persons words and actions and that the people has good intentions to their promises (Snyder et al., 2017). In the midst of employee behavior tend toward individually, thus they will show negative reactions on each motivation, and inspirations given if distrust happened.

\section{Transactional Leadership On Turnover Intention}

Transactional leadership is necessary for the company when managers lead a little number of employees (Hinkin \& Schriesheim, 2008). Structural closeness creates situations that are controlled by transactional leadership because employees and managers are more likely to interact each other (Moon \& Park, 2019). The certain branch of banking sector is classified as having a small number employees namely 253 permanent employees, when compared to those industry the number is relatively small and it classified as a small industry. Transactional leadership focused on the fulfillment of contracts between employees and managers (Jensen et al., 2019), it's essential for managers to give a considerable amount of energy and time to evaluate the success which employees achieve and their task responsibilities. A small numbers of employees may provide more feedback and role clarification about fulfilling expectations rather than leaders with a large number of employees (Sithole \& Sudha, 2014). The impact of COVID 19 pandemic has made almost everyone focus more on health and daily needs (Baum et al., 2020), they will strongly agree if their work is exchanged for equivalent benefit, this makes the transactional leadership dimension more in line with current conditions. Job clarity, rewards, and measurable leadership abilities make employees comfortable in work. Employees may be more motivated by rewards under current conditions, and have more confidence in the decisions of their leaders because of the suitability of workload and compensation offered, thus making them discouraged and keep their intention to leave the bank. The role of transactional leadership is also supported by banks which have a very structured system, where employees are very obedient to the established standard operating procedures (SOP). It is also supported by our descriptive result in which "reward employee achievement" has a $73 \%$ highest response with mean value 3,63> other questions, and lowest mean value is "delay responding", this has proven that the leaders at the banking sector almost certainly not delayed responses. Its indicates consistency and informed that the leaders do not display a laissez- faire behavior, our result supported by Deraman et al. (2018)'s finding, which was tested in manufacturing industry in Peninsular Malaysia.

\section{Transformational Leadership On Job Satisfaction}

Transformational leaders have a close relationship with subordinates because of high level direct interaction when leaders motivate and inspire followers, and they do not act like bosses (Mickson \& Anlesinya, 2019). Our descriptive results state that leaders show their strength and belief in work, and things which support work itself, and through that belief they are able to overcome problems related to job satisfaction, then they propose to management, and make satisfactory policies for employees to increase job satisfaction. Participants in this study responded that their leaders raise awareness of important things, job satisfaction is very important, this behavior encourages high levels of employee job satisfaction, in which our descriptive results also state that the leader's had valuable conversations, were optimistic, and very enthusiastic. Furthermore, in this result, leaders also provide space for employees to be creative and innovative, and a sense of empathy makes them look so friendly. Our result was supported by Ho et al. (2016) who conducted their study at local companies in three cities, Da Nang, Hanoi and Ho Chi Minh City, Vietnam. The leader's ability to innovate greatly helps management as a whole in understanding the needs of employees and also has a good creativity in terms of their knowledge. In the midst of COVID 19 pandemic, employees tend to listen to their leaders if their comfort and safety are 
guaranteed, and leaders provide work that makes sense. The results was supported by Alonderiene and Majauskaite (2016).

\section{Transactional Leadership On Job Satisfaction}

In the midst of COVID 19 pandemic, leaders hold a strong role to meet employees needs to avoid demotivation. Leaders with a transactional style have another way of maintaining good performance and employee productivity, they motivate through satisfying rewards and job clarity (Kebede \& Demeke, 2017). Transactional Leadership style demonstrate high interaction with subordinates in which leadership styles with a higher concern for followers, their welfare, autonomy, comfort, encouragement and demonstrate empowerment, recognize and reward employee achievements, showed higher positive influence on job satisfaction (Dartey-Baah \& Ampofo, 2016; Kebede \& Demeke, 2017; Mickson \& Anlesinya, 2019). Our research results complemented result of Alonderiene and Majauskaite (2016) in Lithuania, in which employees indicated that they are more satisfied and motivated by leaders who possess assertive, great energy, high levels of self-confidence, ideals, strong beliefs, and use satisfying reward systems. This result was also supported by the study of Mickson and Anlesinya (2019) who conducted a quantitative study with 322 usable data. They found that transactional leadership has a significant and positive effect on job satisfaction, this result implies that when leaders' demonstration of transactional leadership behaviors increases, it will lead to enhancement in job satisfaction. In the context of a relationship between managers and employees amid COVID 19, contingent reward leadership might make it possible to knowing the unique desires of employees, tailor extrinsic rewards to employees (Moon \& Park 2019), and to handle current conditions through maximizing employee satisfactions.

\section{Job Satisfaction On Turnover Intention}

The higher the level of employee satisfaction, the lower their desire to leave the company. They will enjoy their job during COVID 19 pandemic when job security is guaranteed, facilities are fulfilled, a comfortable environment is provided, an appropriate workload is given, and satisfying benefits are rewarded. It is also supported by the result of descriptive analysis in which an average participant's response on all indicators used were classified as high. And when referring to employee preferences, employees inbanking sector prefer to work in the office Post COVID 19 Pandemic than doing work from home, because since June 2020 they have no longer been doing WFH due to the New Normal Regulation from West Sumatera Government. And it indicates that employees are supported by good facility and friendly colleagues.

Furthermore, participants profile also supports that nearly one hundred percent of employees stated that their job placement was appropriate, and employees also had an average salary above IDR 6 million. This of course will be an important consideration for employees to leave their current workplace. Thus, organizations must concentrate on enriching job satisfaction to retain talented employees, and reduce employee turnover. It has been argued that employee behavior, emotions, and attitude in the company are important because they represent employee job satisfaction (Rajabi et al., 2019). If we refer to Job satisfaction score, they may not leave in near future, or even think to leave banking sector, because almost all of their needs are met. The results of this study are supported by research of (Hassan \& Jagirani, 2019) which is conducted on the banking sector in Pakistan, who found that job satisfaction has negative and significant effect on employee turnover intention. It means that if employees feel satisfied, they tend to be loyal with the organization and vice versa (Griffiths \& Royse, 2017). In China, Zhang et al. (2019) which has conducted a survey in electricity companies in Shandong Province also support our result. This indicates that job satisfaction is really important factor to maintain employee negative perception and desire to leave.

\section{Transformational Leadership, Job Satisfaction, Turnover Intention}

With regards to increasing needs of employees during COVID-19 pandemic, the influence of leaders has begun to be questioned and their image has begun to be put at stake. Quality assurance of safety and security, as well as the availability of working facilities have become things that must be provided and improved in current situation. It will serve as an impetus for avoiding the under-performance that may result from fear and high levels of stress during the COVID-19 pandemic (Aguinis et al., 2020). Whereas, basically amid COVID 19 pandemic, the tendency of people's characteristics in general will change to become more individualistic (Almeida \& Santos, 2020). Thus, when employees are satisfied with overall job satisfaction, they will be easily motivated and directed (Mwesigwa et al., 2020). Job satisfaction will generate trust, trust will affect employee attitudes and behavior (Yanney, 2014). In study (Guevara et al., 2019) argues that the results of trust starting from a person's belief, and the ability of people to express trust in others are built through the honesty of the leader and the value of strength (Osman et al., 2016). Employees will have a positive perception about words and approaches of their leaders when their needs are met. A high level of trust is usually expressed through admitting mistakes, understanding each other, always share information honestly, have good communication, promote integrity and maintain transparency (Osman et al., 2016). It was proven by the results of this study, in which job satisfaction has succeeded in mediating the effect between transformational leadership and employee turnover intention during COVID 19 pandemic at the banking sector. Supported by open questions asked, we found that $77.79 \%$ of the participants prefers to work in office (WFO), while $19.60 \%$ prefer mix WFH and WFO, and only $2.61 \%$ chose Full WFH in Post-COVID 19. We argue that employees feel more comfortable and secure when they work in the office, in which complete facilities are provided in a good environment. So that they are more able to focus on the job task. The mediating impact of employee job satisfaction has made transformational leadership style which initially had a positive effect on turnover intention, turned into a negative effect on turnover intention with a total effect of $76,77 \%$ contributed in role enhancement. It indicates that without job satisfaction transformational leadership role will never be maximized, or even 
have no impact to mitigate turnover intention Furthermore, strong impact of job satisfaction is also supported by study of (Wang et al., 2020), who tested job satisfactions as mediator on turnover intentions, and it has been found significant result on turnover intention, by using job satisfaction as a mediator can deepen our understanding on how job satisfaction enrich the role of transformational leadership, make employees trust their leader, and has a strong commitment. So that transformational leadership can mitigate turnover intention of bank employees.

\section{Transactional Leadership, Job Satisfaction, Turnover Intention}

Job satisfaction was considered to be an important factor for getting employees to perform as expected and accomplish job tasks on time, and encouraging leaders to treat such issues with all the interest they deserve. Then they will give rewards if their expectations are met, then it will bring pleasure and satisfaction for employees (Bekiari \& Ntakou, 2018). So, subordinates will recognize that the leader has high quality and power to influence job satisfaction. Leaders who are reward-based and express job clarity will be encouraged by employee job satisfaction amid the COVID 19 pandemic, because job satisfaction also reduces employee stress levels (Alkhamees et al., 2020). Thus, their behavior reflects turnover intention decisions. It was also stated from this study, that employees are satisfied with their jobs if managers offered positive rewards, closely monitored, and doing corrections before they deviated from assigned tasks (Dartey-Baah \& Ampofo, 2016), especially in COVID 19 pandemic. Employee satisfaction with their leaders, either personal or performance, will create a feeling of reluctance for employees to leave banking sector. On the other hand, the high response to the "satisfy with colleague" dimension makes employees feel comfortable with the tasks assigned by their leaders. When they find it difficult to solve their job problems or represent work to colleagues for some reason, they will believe that the represented task can meet the expectations of the leaders. Transactional leaders are leaders who are structured and a little rigid, where they are more focused on the work of their subordinates (Reid \& Dold, 2018), a systematic, structured banking system, working based on SOPs also supports transactional leadership roles, but their rigid nature and distant relationship to employees will have an impact on boredom towards the job (Mews, 2019). In an effort to overcome this saturation, management of banking sector is required to increase their overall job satisfaction. In this context, transactional leaders understand the unique needs of employees because they are driven by reward-based behavior (Mwesigwa et al., 2020). This study was also supported by research of Wang et al. (2020) who found that job satisfaction was succeeded became mediator in their study. Additionally, strong and negative effect of transactional leadership on turnover intention through job satisfaction has given good impact to employee behavior and perception about leaders (Ghosh et al., 2015).

\section{Conclusion}

The complexity in managing global business operations will lead to uncertainty and fluctuations in market demands (Fernando et al., 2020). In the midst of COVID 19 pandemic situation, transformational dimension does not match efforts to mitigate the level of turnover intention directly when inconsistent leadership roles occurred, especially in regional banking. The tendency of employees to behave individually make them more concerned with benefit offered, which can be felt directly during pandemic (Bhardwaj et al., 2020). Transactional leadership with reward-punishment based leadership and task-oriented make it in line with these conditions when leaders can give them about job clarity.

Job satisfaction provides feedback in enhancing transformational and transactional leadership role and quality in mitigating turnover intention, in addition to our result which states that majority of participants satisfied with their overall job satisfaction. It encouraged the roles of both transformational and transactional leadership in banking industry amid COVID 19 Pandemic, because limited communication, and interaction makes employees more concerned with job clarity, and rewards which can be used in current situation rather than conversations which lead to long-term goals of the company or something happen in the future. Transformational leadership with engagement and closeness to employees, while transactional leaders with assertiveness, clarity of work, and rewards given as a replacement for their performance and productivity amid COVID 19 Pandemic. Employee job satisfaction cannot be underestimated, because it will have an impact on the trust and respect of subordinates to their leader, and will influence the relationship between employees and their leader.

\section{Research implications}

Implication For Practice

The higher job satisfaction will help to maximize quality and role of leaders in efforts to mitigate the level of turnover intention. Therefore, it is important for banking sector to increase and upgrade the level of employee job satisfaction. If employee job satisfaction is not increased or updated, the role of leaderships will be weak, or cannot contribute maximally in mitigating turnover intention, this is evidenced by the total effect of job satisfaction as much as $76.74 \%$ in enhancing transformational leadership, and $27.54 \%$ to transactional leadership, meaning that job satisfaction is a really important factor in enriching the role and quality of leaders to mitigate turnover rate. If a problem was found related to job satisfaction then it cannot be ignored and must be corrected immediately. Job satisfaction will eliminate stiffness and create a flexible relationship between subordinates and leaders, and it is also an important factor for retaining employees, so that there are no negative thoughts about the management of banking sector.

\section{Implication For Study}

The suitability of a leadership style for an organization or company must be tested periodically to adapt with times, especially when researching companies owned and managed by local governments. It is very important to measure and evaluate job satisfaction in the relationship between leaders and subordinates in order to maintain the quality of employees 
and mitigate turnover rates in a company, especially in the banking sector which is prone to employee turnover. In this case, further research is suggested to develop this research by adding variables related to employee behavior, aspects of sharia, leadership ethics, external environment, organizational commitment, organizational trust, and others. As a result, it will be able to contribute to management in applying a suitable leadership style for the organization through the mediation of variables that are closely related to the work environment of employees, leaderships and religion. On the other hand, the result we found on the direct effect of transformational leadership, which has a positive effect on turnover intention during COVID 19 Pandemic, can also be used as a comparison for future research. Furthermore, by considering the limited number of studies that currently exists on leadership style preferences of follower's perspective, there is a great opportunity for continued examination of this viewpoint.

\section{Recommendations}

To mitigate employee intention to resign from banking sector due to religious issue. Conventional bank is recommend to shift to be Sharia Bank. It is supported by majority of participants prefer sharia bank in work preference and $100 \%$ of participants are Muslim. In the context of leadership, a consistency is needed from the leader in his actions and words, so that employees trust to their leaders can be achieved. When leaders emphasize a common mission, leaders are expected to serve common interests and they goes beyond their self-interest, because discrepancy seen between what the leaders said and employee seen every day will have a negative impact to employee trust and confidence, and will create less harmonious relationship between leaders and employees. In terms of job satisfaction, banking sector is advised to look at aspects of employee education in career advancement, because if employees who have higher education have never been promoted because they come from regions or universities that do not contribute much in contributing employees to banking sector, these things will trigger their desire to resign, in which most employees who easily leave the organization are employees who have high education and experience, because they feel able to find better jobs. Besides, to increase satisfaction regarding career paths at the bank, new regulations are needed which is focused on transparency in clarity of promotion time, level of education, and achievement required.

\section{Limitations}

There are several limitations in this study includes; we have not found much support literature regarding our finding in direct relationship between transformational leadership and turnover intention amid COVID 19 pandemic, and also no specific theory included in theoretical literature regarding behavioural aspect duing COVID 19 pandemic, then our mediator was only job satisfaction.

\section{Acknowledgement}

The authors are grateful to Editor-in-Chief and anonymous reviewers for their valuable comments and suggestions.

\section{References}

Ab Hamid, M. R., Sami, W., \& Mohmad Sidek, M. H. (2017). Discriminant Validity Assessment: Use of Fornell \& Larcker criterion versus HTMT Criterion. Journal of Physics: Conference Series, 890(1). https://doi.org/10.1088/1742-6596/890/1/012163

Adiguzel, Z., Ozcinar, M. F., \& Karadal, H. (2020). Does servant leadership moderate the link between strategic human resource management on rule breaking and job satisfaction? European Research on Management and Business Economics, 26(2), 103-110. https://doi.org/10.1016/j.iedeen.2020.04.002

Aguinis, H., Villamor, I., \& Gabriel, K. P. (2020). Understanding employee responses to COVID-19: a behavioral corporate social responsibility perspective. Management Research, 18(4), 421-438. https://doi.org/10.1108/MRJIAM-06-2020-1053

Alghamdi, F. S. (2015). Another Look at Job and Life Satisfaction among Employees: Evidence from a Developing Country. American Journal of Industrial and Business Management, 05(01), 11-19. https://doi.org/10.4236/ajibm.2015.51002

Alkhamees, A. A., Alrashed, S. A., Alzunaydi, A. A., Almohimeed, A. S., \& Aljohani, M. S. (2020). The psychological impact of COVID-19 pandemic on the general population of Saudi Arabia. Comprehensive Psychiatry, 102, 152192. https://doi.org/10.1016/j.comppsych.2020.152192

Almeida, F., \& Santos, J. D. (2020). The effects of COVID-19 on job security and unemployment in Portugal. International Journal of Sociology and Social Policy. https://doi.org/10.1108/IJSSP-07-2020-0291

Alonderiene, R., \& Majauskaite, M. (2016). Leadership style and job satisfaction in higher education institutions. International Journal of Educational Management, 30(1), 140-164. https://doi.org/10.1108/IJEM-08-2014-0106

Amankwaa, A., \& Anku-Tsede, O. (2015). Linking Transformational Leadership to Employee Turnover: The Moderating Role of Alternative Job Opportunity. International Journal of Business Administration, 6(4). https://doi.org/10.5430/ijba.v6n4p19

Anis Amirah Muhd Suberi. (2013). Review on leadership style among TVET lecturers. International Journal of Science and Research, 4(5), 2619-2622. https://www.ijsr.net/

Avolio, B. J., Bass, B. M., \& Jung, D. I. (1999). Re-examining the components of transformational and transactional leadership using the multifactor leadership questionnaire. Journal of Occupational and Organizational Psychology, 72(4), 441-462. https://doi.org/10.1348/096317999166789 
Awan, M. R., \& Mahmood, K. (2010). Relationship among leadership style, organizational culture and employee commitment in university libraries. Library Management, $253-266$. https://doi.org/10.1108/01435121011046326

Bass, B. M., \& Avolio, B. J. (1993). Transformational Leadership and Organizational Culture. International Journal of Business- Regulatory Integrative and Comparative Physiology, $16(3), \quad 10$. https://doi.org/10.1152/ajpregu.1984.247.3.r405

Bass, B. M., \& Avolio, B. J. (2004). Avolio, B. J., \& Bass, B. M. (2004). Leadership style in organizations. Industrial/Organizational Psychology, 1, 15.

Baum, T., Mooney, S. K. K., Robinson, R. N. S., \& Solnet, D. (2020). COVID-19's impact on the hospitality workforce - new crisis or amplification of the norm? International Journal of Contemporary Hospitality Management, 32(9), 2813-2829. https://doi.org/10.1108/IJCHM-04-2020-0314

Bekiari, A., \& Ntakou, V. (2018). Insights to Argumentativeness in Relation to Leadership Style and Job Satisfaction: Using Employees' Sport Organizations as an Illustration. Open Journal of Leadership, 07(01), 1-18. https://doi.org/10.4236/oj1.2018.71001

Bhardwaj, A., Mishra, S., \& Kumar Jain, T. (2020). An analysis to understanding the job satisfaction of employees in banking industry. Materials Today: Proceedings, xxxx. https://doi.org/10.1016/j.matpr.2020.04.783

Bright, J. B. (2018). The relationship between transformational leadership behaviors and employee engagement and turnover intent. ProQuest Dissertations and Theses, 1-131.

Burns, J. M. G. (2005). Leadership. Leadership, 1(1), 11-12. https://doi.org/10.1177/1742715005049347

Carlson, J. R., Carlson, D. S., Zivnuska, S., Harris, R. B., \& Harris, K. J. (2017). Applying the job demands resources model to understand technology as a predictor of turnover intentions. Computers in Human Behavior, 77, 317-325. https://doi.org/10.1016/j.chb.2017.09.009

Castle, N.G., Engberg, J. and Anderson, R. . (2007). Job satisfaction of nursing home administrators and turnover. Medical Care Research \& Review, 64, p. 19(1), 14.

Dalton, D. R., \& Todor, W. D. (1979). Turnover Turned over: An Expanded and Positive Perspective. The Academy of Management Review, 4(2), 225. https://doi.org/10.2307/257776

Dartey-Baah, K., \& Ampofo, E. (2016). “Carrot and stick” leadership style: Can it predict employees' job satisfaction in a contemporary business organisation? African Journal of Economic and Management Studies, 7(3), 328-345. https://doi.org/10.1108/AJEMS-04-2014-0029

Deraman, N., Nor, N. N. M., \& Zainuddin, N. (2018). Transactional leadership style on turnover intention among electrical and electronic sub-sector employees in Malaysia. Journal of Technology and Operations Management, $13(1), 42-54$.

Dunn, W. R., Lyman, S., \& Marx, R. (2003). Research methodology. Arthroscopy - Journal of Arthroscopic and Related Surgery, 19(8), 870-873. https://doi.org/10.1016/S0749-8063(03)00705-9

Fallatah, F., Laschinger, H. K. S., \& Read, E. A. (2017). The effects of authentic leadership, organizational identification, and occupational coping self-efficacy on new graduate nurses' job turnover intentions in Canada. Nursing Outlook, 65(2), 172-183. https://doi.org/10.1016/j.outlook.2016.11.020

Fernando, Y., Zainul Abideen, A. and Shaharudin, M.S. (2020), The nexus of information sharing, technology capability and inventory efficiency, Journal of Global Operations and Strategic Sourcing, 33(4), 327-351.

Fernando, Y. and Wulansari, P. (2021), Perceived understanding of supply chain integration, communication and teamwork competency in the global manufacturing companies, European Journal of Management and Business Economics, Vol. ahead-of-print No. ahead-of-print.

Fernando, Y., Rozuar, N. H. M., \& Mergeresa, F. (2021). The blockchain-enabled technology and carbon performance: Insights from early adopters. Technology in Society, 64, 101507.

Fulcher, G. M., \& Smith, R. J. (2010). Environmental correlates of public child welfare worker turnover. Administration in Social Work, 34(5), 442-457. https://doi.org/10.1080/03643107.2010.518530

Fornell, C., \& Larcker, D.F. (2012). Claes Fornell and David F. Larcker. (2012). Equation Algebra Unobservable Error : Variables. Journal of Marketing Research, 18(3), 382-388.Equation Algebra Unobservable Error: Variables. Journal of Marketing Research, 18(3), 382-388.

Ghosh, P., Rai, A., Chauhan, R., Gupta, N., \& Singh, A. (2015). Exploring the moderating role of context satisfaction between job characteristics and turnover intention of employees of Indian public sector banks. Journal of Management Development, 34(8), 1019-1030. https://doi.org/10.1108/JMD-10-2014-0138

Grau, A. J., \& Heuschmann, P. U. (2020). Health services research. Nervenarzt, 91(6), 475-476. https://doi.org/10.1007/s00115-020-00910-3

Griffiths, A., \& Royse, D. (2017). Unheard Voices: Why Former Child Welfare Workers Left Their Positions. Journal of Public Child Welfare, 11(1), 73-90. https://doi.org/10.1080/15548732.2016.1232210

Guevara, R. S., Montoya, J., Carmody-Bubb, M., \& Wheeler, C. (2019). Physician leadership style predicts advanced practice provider job satisfaction. Leadership in Health Services, 33(1), 56-72. https://doi.org/10.1108/LHS-062019-0032

Gul, S., Ahmad, B., Ur Rehman, S., Shabir, N., \& Razzaq, N. (2012). Leadership Styles, Turnover Intentions and the Mediating Role of Organizational Commitment. Information and Knowledge Management, 2(7), 44-51.

Hair, J. F., Sarstedt, M., Hopkins, L., \& Kuppelwieser, V. G. (2014). Partial least squares structural equation modeling (PLS-SEM): An emerging tool in business research. European Business Review, 26(2), 106-121. 
https://doi.org/10.1108/EBR-10-2013-0128

Hamid, Mahmud, Wahab, Sazali Abdul, Hosna, A. U. (2020). THE INTERNATIONAL JOURNAL OF BUSINESS \& MANAGEMENT Impact of Coronavirus ( COVID-19) and Employees 'Reaction to Changes on Employee Performance of Bangladesh. 8(8), 34-43. https://doi.org/10.24940/theijbm/2020/v8/i8/BM2008-013

Han, E. S., \& goleman, daniel; boyatzis, Richard; Mckee, A. (2019). 済無No Title No Title. Journal of Chemical Information and Modeling, 53(9), 1689-1699.

Hassan, M., \& Jagirani, T. S. (2019). Employee turnover in public sector banks of Pakistan. Market Forces, 14(1). http://www.pafkiet.edu.pk/marketforces/index.php/marketforces/article/download/390/338

Hassi, A. (2019). "You get what you appreciate": Effects of leadership on job satisfaction, affective commitment and organisational citizenship behaviour. International Journal of Organizational Analysis, 27(3), $786-811$. https://doi.org/10.1108/IJOA-08-2018-1506

Heale, R., \& Twycross, A. (2015). Validity and reliability in quantitative studies. Evidence-Based Nursing, $18(3), 66-67$. https://doi.org/10.1136/eb-2015-102129

Henseler, J., Ringle, C. M., \& Sarstedt, M. (2014). A new criterion for assessing discriminant validity in variance-based structural equation modeling. Journal of the Academy of Marketing Science, 43(1), 115-135. https://doi.org/10.1007/s11747-014-0403-8

Herschell, A. D., Kolko, D. J., Hart, J. A., Brabson, L. A., \& Gavin, J. G. (2020). Mixed method study of workforce turnover and evidence-based treatment implementation in community behavioral health care settings. Child Abuse and Neglect, 102(February), 104419. https://doi.org/10.1016/j.chiabu.2020.104419

Hinkin, T. R., \& Schriesheim, C. A. (2008). A theoretical and empirical examination of the transactional and nonleadership dimensions of the Multifactor Leadership Questionnaire (MLQ). Leadership Quarterly, 19(5), 501-513. https://doi.org/10.1016/j.leaqua.2008.07.001

Hinojosa, A. S., Shaine, M. J. D., \& McCauley, K. D. (2020). A strange situation indeed: Fostering leader-follower attachment security during unprecedented crisis. Management Decision. https://doi.org/10.1108/MD-08-2020-1142

Ho, V., Dinh, T., \& Vu, M. (2016). Transformational and transactional leadership styles and employees' job satisfaction in Vietnamese local companies. International Review of Management and Business Research, 5(3), 938-950.

Hurt, K. J., Huning, T. M., \& Thomson, N. F. (2017). Understanding Servant Leadership's Influence on Turnover Intentions and Job Satisfaction: The Mediating Role of Perceived Organizational Support and Job Embeddedness. The Journal of Applied Management and Entrepreneurship, 22(2), 26-38. https://doi.org/10.9774/gleaf.3709.2017.ap.00004

Jensen, U. T., Andersen, L. B., Bro, L. L., Bøllingtoft, A., Eriksen, T. L. M., Holten, A. L., Jacobsen, C. B., Ladenburg, J., Nielsen, P. A., Salomonsen, H. H., Westergård-Nielsen, N., \& Würtz, A. (2019). Conceptualizing and Measuring Transformational and Transactional Leadership. Administration and Society, 51(1), 3-33. https://doi.org/10.1177/0095399716667157

Jr, J. F. H., William C. Black, Babin, B. J., \& Rolph E. Anderson. (2010). Multivariate Data Analysis (Seventh). Pearson Prentice Hall.

Kebede, A. M., \& Demeke, G. W. (2017). The Influence of Leadership Styles on Employees' Job Satisfaction in Ethiopian Public Universities. Contemporary Management Research, 13(3), 165-176. https://doi.org/10.7903/cmr.17668

Khajeh, E. H. Al. (2018). Impact of Leadership Styles on Job Satisfaction. Batool \& Ikram, $2018,2306-9007$. https://doi.org/10.5171/2018.939089

Koesmono, H. T. (2017). The Effects of Transactional Leadership on Employees' Turnover Intention at PT. Sumber Alfaria Trijaya Tbk. (Mini Market Alfamart) East Surabaya Region, Indonesia Using Job Involvement, Work Motivation, and Job Satisfaction as Mediating Variables. Journal of Resources Development and Management, 29(1999), 66-73. https://www.iiste.org/Journals/index.php/JRDM/article/view/35649/36669

Krejcie, R. V., \& Morgan, D. W. (1970). Determining Sample Size for Research Activities. Educational and Psychological Measurement, 30(3), 607-610. https://doi.org/10.1177/001316447003000308

Lee, C., \& Way, K. (2010). Individual employment characteristics of hotel employees that play a role in employee satisfaction and work retention. International Journal of Hospitality Management, 29(3), 344-353. https://doi.org/10.1016/j.ijhm.2009.08.008

Maaitah, A. M. (2018). International Review of Management and Marketing The Role of Leadership Style on Turnover Intention. International Review of Management and Marketing, 8(5), 24-29.

Mews, J. G. (2019). Effective Leadership in Higher Education: A Review of Leadership Style Preferences among Faculty and Staff within the United States. Open Journal of Leadership, 08(02), 58-74. https://doi.org/10.4236/oj1.2019.82004

Mickson, M. K., \& Anlesinya, A. (2019). Enhancing job satisfaction among local government servants in Ghana. International Journal of Public Leadership, 16(1), 1-16. https://doi.org/10.1108/ijpl-03-2019-0007

Mohter, N., \& Fernando, Y. (2020). Corporate Governance and Low Carbon Supply Chains: Why Integrity Matters?. Journal of Governance and Integrity, 3(2). https://doi.org/10.15282/jgi.3.2.2020.5308

Monitor, I. L. O. (2020). COVID-19 and the world of work: Impact and policy responses; Current situation: Why are labour markets important? March, 1-15. https://gisanddata.maps.arcgis.com/apps/opsdashboard/index.html\#/bda7594740fd40299423467b48e9ecf6.CEPR. https://voxeu.org/content/economics-time-covid193SeeforexampleUNCTAD,https://unctad.org/en/pages/PressRelease. aspx ?OriginalVersionID=548 
Moon, K. K., \& Park, J. (2019). Leadership Styles and Turnover Behavior in the US Federal Government: Does Span of Control Matter? International Public Management Journal, 22(3), $417-443$. https://doi.org/10.1080/10967494.2018.1557767

Mwesigwa, R., Tusiime, I., \& Ssekiziyivu, B. (2020). Leadership styles, job satisfaction and organizational commitment among academic staff in public universities. Journal of Management Development, 39(2), $253-268$. https://doi.org/10.1108/JMD-02-2018-0055

Ngoma, M., Namono, R., Nangoli, S., Bashir, H., \& Nakyeyune, S. (2020). Towards fighting COVID-19 : can servant leadership behaviour enhance commitment of medical. https://doi.org/10.1108/CRR-05-2020-0018

Nolan-Arañez, S. I., \& Ludvik, M. B. (2018). Positing a framework for cultivating spirituality through public university leadership development. Journal of Research in Innovative Teaching \& Learning, 11(1), 94-109. https://doi.org/10.1108/jrit-08-2017-0018

O’Fallon, W. M., Cooley, W. W., \& Lohnes, P. R. (1973). Multivariate Data Analysis. Technometrics, $15(3), 648$. https://doi.org/10.2307/1266874

Osman, I., Noordin, F., Daud, N., \& Othman, M. Z. (2016). The Dynamic Role of Social Exchange and Personality in Predicting Turnover Intentions among Professional Workers. Procedia Economics and Finance, 35(October 2015), 541-552. https://doi.org/10.1016/s2212-5671(16)00067-8

Park, T., \& Pierce, B. (2020). Impacts of transformational leadership on turnover intention of child welfare workers. Children and Youth Services Review, 108(September 2019), 104624. https://doi.org/10.1016/j.childyouth.2019.104624

Rajabi, R., Boles, J., Brashear Alejandro, T. G., \& Sarin, S. (2019). Revisiting and replicating the dominant logic on salesperson job satisfaction, organizational commitment, and turnover. Journal of Business Research, October, 01. https://doi.org/10.1016/j.jbusres.2019.10.067

Ramalho Luz, C. M. D., Luiz de Paula, S., \& de Oliveira, L. M. B. (2018). Organizational commitment, job satisfaction and their possible influences on intent to turnover. Revista de Gestão, 25(1), 84-101. https://doi.org/10.1108/rege12-2017-008

Randeree, K., \& Chaudhry, A. G. (2012). Leadership - Style, satisfaction and commitment: An exploration in the United Arab Emirates' construction sector. Engineering, Construction and Architectural Management, 19(1), 61-85. https://doi.org/10.1108/09699981211192571

Reid, W. M., \& Dold, C. J. (2018). Burns, Senge, and the Study of Leadership. Open Journal of Leadership, 07(01), 89116. https://doi.org/10.4236/oj1.2018.71006

Sahu, S., Pathardikar, A., \& Kumar, A. (2018). Transformational leadership and turnover: Mediating effects of employee engagement, employer branding, and psychological attachment. Leadership and Organization Development Journal, 39(1), 82-99. https://doi.org/10.1108/LODJ-12-2014-0243

Sanjeev, M. A. (2017). Impact of Individual and Employment Variable on Job Satisfaction \& Turnover Intention among Sales and Marketing Professionals. Procedia Computer Science, 122, 55-62. https://doi.org/10.1016/j.procs.2017.11.341

Scanlan, J. N., \& Hazelton, T. (2019). Relationships between job satisfaction, burnout, professional identity and meaningfulness of work activities for occupational therapists working in mental health. Australian Occupational Therapy Journal, 66(5), 581-590. https://doi.org/10.1111/1440-1630.12596

Sekaran, U., \& Bougie, R. (2011). Research Methods for Business: A Skill-Building Approach, 6th Edition.

Silva. (2013). The absence of qualified professionals in a determined region. 20.

Sithole, A., \& Sudha, S. (2014). Transactional leadership style and employees' turnover intention in information technology organizations. International Journal of Case Studies, 4(10). 78-82.

Snyder, N. H., Graves, M., Tzu, L., \& Ralp Waldo Emerson. (2017). Leadership Today. In Business Horizons (Vol. 37, Issue 1). https://doi.org/10.1016/S0007-6813(05)80220-4

Spector, P. (1997). Job Satisfaction. Application, Assessment, Causes and Consequences. Sage Publications, London, 1, 23.

Stamolampros, P., Korfiatis, N., Chalvatzis, K., \& Buhalis, D. (2019). Job satisfaction and employee turnover determinants in high contact services: Insights from Employees'Online reviews. Tourism Management, 75(May), 130-147. https://doi.org/10.1016/j.tourman.2019.04.030

Tajaddini, R., \& Mujtaba, B. G. (2011). Stress and Leadership Tendencies of Respondents from Iran: Exploring Similarities and Differences Based on Age and Gender. Public Organization Review, 11(3), $219-236$. https://doi.org/10.1007/s11115-010-0118-3

Takase, M. (2010). A concept analysis of turnover intention: Implications for nursing management. Collegian, 17(1), 312. https://doi.org/10.1016/j.colegn.2009.05.001

Wahyuni-TD, I.S., Haron, H. and Fernando, Y. (2021), "The effects of good governance and fraud prevention on performance of the zakat institutions in Indonesia: a Sharī'ah forensic accounting perspective", International Journal of Islamic and Middle Eastern Finance and Management, Vol. ahead-of-print No. ahead-of-print. https://doi.org/10.1108/IMEFM-03-2019-0089

Wang, C., Xu, J., Zhang, T. C., \& Li, Q. M. (2020). Effects of professional identity on turnover intention in China's hotel employees: The mediating role of employee engagement and job satisfaction. Journal of Hospitality and Tourism Management, 45(June), 10-22. https://doi.org/10.1016/j.jhtm.2020.07.002

Wells, J. E., \& Peachey, J. W. (2011). Turnover intentions: Do leadership behaviors and satisfaction with the leader 
matter? Team Performance Management, 17(1), 23-40. https://doi.org/10.1108/13527591111114693

Westover, J. H. (2014). Leading Innovative Organizations Series (Creative Commons Attribution-NonCommercial ShareAlike 3.0 License (ed.)). HCI Press, Library of Congress Cataloging-in-Publication Data. http://www.saylor.org/books

Wu, C. H., \& Parker, S. K. (2017). The Role of Leader Support in Facilitating Proactive Work Behavior: A Perspective From Attachment Theory. Journal of Management, 43(4), 1025-1049. https://doi.org/10.1177/0149206314544745

Xie, Y., Xue, W., Li, L., Wang, A., Chen, Y., Zheng, Q., Wang, Y., \& Li, X. (2018). Leadership style and innovation atmosphere in enterprises: An empirical study. Technological Forecasting and Social Change, 135(May), $257-265$. https://doi.org/10.1016/j.techfore.2018.05.017

Yanney, J. P. (2014). Business Strategy and Leadership Style: Impact on Organizational Performance in the Manufacturing Sector of Ghana. American Journal of Industrial and Business Management, 04(12), 767-775. https://doi.org/10.4236/ajibm.2014.412083

Zhang, X., Ma, L., Xu, B., \& Xu, F. (2019). How social media usage affects employees' job satisfaction and turnover intention: An empirical study in China. Information and Management, 56(6). https://doi.org/10.1016/j.im.2018.12.004

\section{CONFLICT OF INTEREST}

There is no conflict of interest.

\section{AUTHORS' BIOGRAPHY}

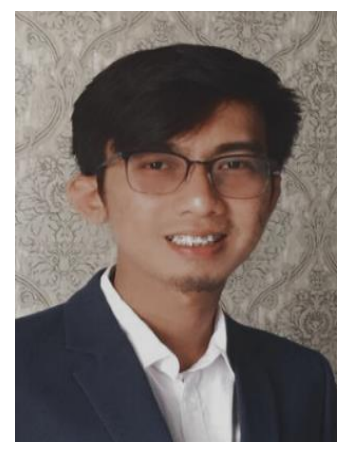

Tedi Hidayat recently completed his Master of Management at Faculty of Economics, Andalas University, Indonesia, and Master of Business Administration at Faculty of Industrial Management, University Malaysia Pahang, Malaysia (2021). A learner and budding writer with an interests Leadership and Marketing. He's active in sailing sports organizations with more than 17 years of experiences, includes: Athlete, Ass. Technical Officer, Ass. Race Officer, Race Officer, and Coach. He has succeeded became a course leader in several National and International Sailing Sport events, and became first young Indonesian Race Officer in Asian Games (2018), and own World Sailing Certificate (2017). He is also Head of Marketing in Karajoelok.com. Email: tedihid@gmail.com

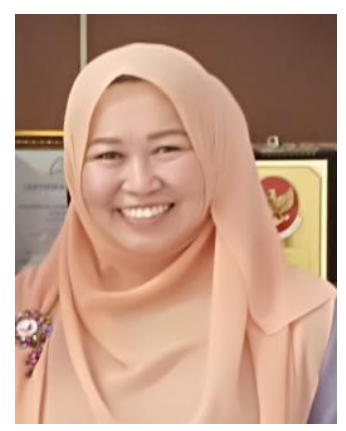

Dr. Rahmi Fahmy, SE, MBA. She is a Senior Lecturer of Human Resources Management at Faculty of Economics, Universitas Andalas since 1993. She completed her Doctor of Business Administration at Southern Cross University, Australia (2006), MBA in Human Resources Management of The University of Philippines (1999). She held several positions includes: As the coordinator of International Program, Secretary and Director of Master Management Program, Head of Senate of Andalas University, and lastly as a Rector of University of Dharma Andalas. Her research focuses on in Human Capital Management, and Character Building. She is also active as motivator and trainer for Business, Education and Government institutions. Email: rahmifahmy@eb.unand.ac.id 


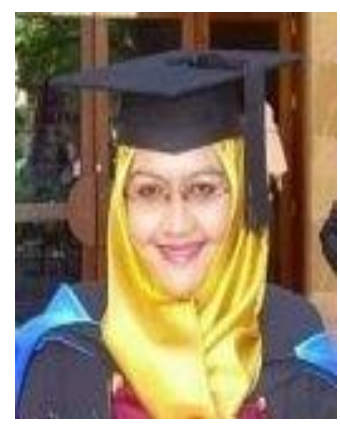

Dr. Dessy Kurnia Sari, SE, M. Buss (Adv). She holds PhD from the UWA Business School, the University of Western Australia. She received a Master of Business (Advanced) from the University of Queensland, Australia. Her research interests focus on Islamic marketing, cross-cultural consumer studies, Muslim consumers, boycott behavior, as well as Muslim's choices of foreign products and brands. She is an Assistant Professor at the Department of Management, Faculty of Economics, Universitas Andalas, Indonesia. She is CO- Founder of karajoelok.com, and really care with disability persons, and disability enterpreneurs, Karajoelok.com aims to be incubator business technology for product of persons with disability. Email: Dessysari55@gmail.com

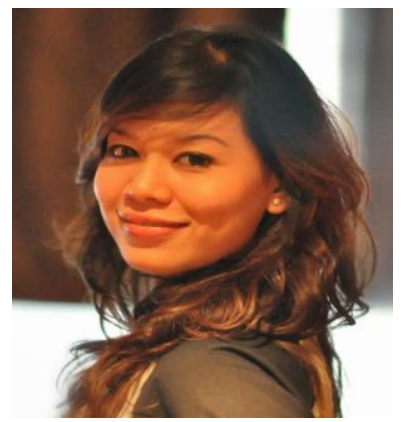

Fineke Mergeresa holds a Master of Management from Faculty of Economics, Universitas Andalas. Prior joined as the research associate, she had vast experience in banking sector. She was a former secretary to the CEO of a government bank in Indonesia. She is currently involved in a research project at the Blockchain and Value Chain research cluster in the Faculty of Industrial Management, Universiti Malaysia Pahang. Fineke has published articles in the field of strategic management, including on Industry 4.0, smart supply chains and the technological adoption of blockchain. Email: fineke.m@gmail.com

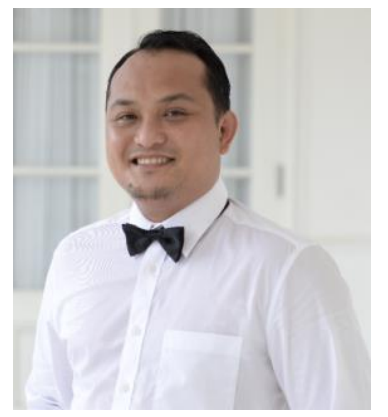

Yudi Fernando holds a Ph.D. and Associate Professor. He is the former Deputy Dean of Research and Postgraduate Studies at the Faculty of Industrial Management, Universiti Malaysia Pahang. He has experience working in the electronics industry for several years. His current research interests are sustainable supply chain management, halal logistics, blockchain technology, and service management. He is also a member of the Society of Logisticians, Malaysia/Pertubuhan Pakar Logistik Malaysia (LogM). Email: yudi@ump.edu.my 